\title{
Telecommunications Revolution: Implications on Criminality and Family Crisis in the South-South States of Nigeria
}

\author{
AGBA, A. M. OGABOH \\ Department of Sociology, University of Calabar, Calabar, Nigeria \\ Tel: 2-34-080-7272-7272Ｅ-mail: ogabohagbagroup@yahoo.com
}

IKOH, MOSES

NIPOST, Benue State, Nigeria

USHIE, E.M. \& BASSEY, A. O.

Department of Sociology, University of Calabar, Calabar, Nigeria

\begin{abstract}
In recent times telecommunications revolution especially the use of mobile phones is transforming the Nigerian society in many ways. The socio-economic and cultural impacts are enormous. As the spectrum of mobile phone usage increases, opinion differs among users on the impact of this revolution in Nigerian. This paper therefore set to investigate the impact of telecommunications revolution especially text based messages on criminality and family crisis in Nigeria. In doing this, the study elicited data through questionnaire from 7200 respondents who were randomly and purposively selected. Analysis of this data revealed that, most Nigerians were duped through text messages, while significant numbers of marriages are in crisis due to spouse assess to text messages that suggest suspicious of infidelity among partners. We recommended among others that Nigerian should scrutinize text messages before reacting to its content and that proper documentation of Sims pack users is necessary.
\end{abstract}

Keywords: Telecommunications revolution, Family crisis, Criminality information and communication technology

\section{Introduction}

The role of Information and Communication Technology (ICT) as a tool for development has received substantial attention since the turn of this century (Offurum, 2009; Keil \& Johnson, 2005; Trevino, Webster \& Stein, 2006). The term ICT has been used to encompass technological innovation and convergence in information and communication. The sector consists of a complex and heterogeneous set of goods, applications and services used to produce, process, distribute and transmit information (Nath, 2000). Its contribution to the emergence of information or knowledge societies(Marcelle,2000); changes in social interaction, economic and business practices, political engagement, education, health, leisure and entertainment, informed the United Nations Organization (UNO) declaration of May $24^{\text {th }}$ every year as the World Communication Day (Offurum,2009).

The emergence of ICT has brought a new era in communication revolution to Nigeria. The internet, mobile phone and computer, all of which superseded hitherto used communication devices like cables and telegrams, have brought about a fundamental shift in patterns of communication and human relationships. These new technologies in communication satellites enable sound, images and messages, to reach target audience almost simultaneously. It is possible to record messages, stored them, retrieve and use at will. Communication revolution has brought about amazing social, economic, cultural and psychological transformation. It has reduced the globe into a village through reduction of time and space (Keil \& Johnson, 2005). The crucial implications of this are numerous. It is promoting a culture of respect, dialogue and friendship (Offurum, 2009).

There is a growing understanding among researchers that Mobile-phone Mediated Communication (MMC) has made it possible for people to receive messages without having to meet face to face. Mobile phone thus becomes a powerful instrument for networking participation and advocacy within the society, advancing socio-economic development through the creation of new types of economic activities and employment opportunities. Text message is one type of MMC that allows for both one to one and one- to many textual communications without regard to an individual physical 
location. It has provided the means to satisfy man's innate desires for connectedness and man's desire to reach beyond himself and commune with others.

In spite of the benefits of MMC in fostering contact, advancing economic and social development through enhanced network, various opinion polls suggest that MMC has been employed into criminal activities such as pornography, frauds, hates and obtaining goods by trick (OBT). Such ugly situation has received very little attention. There is equally no previous attempt to explore the impact of text based messages on family crisis. The family is the fundamental unit of society (Otte \& Ogionwo, 2006; Giddens, 2006). It remains a vital ground for testing how people use objects (Carrier, 1990). Text based message through mobile- phone mediated communication (MMC) link families and individual members within the family, as well as the world beyond their front doors. How they do this or fail to do it involves a complex and often contradictory ways, which has threatened many marriages and the unity of many homes. Causal observation equally reveals the disruption of marriage engagements due to cheating discovered through MMC by either the fiancé or the fiacee. Such development is capable of generating ill feelings that can impact negatively on the well-being of society members. Accurate understanding of such developments is needed for dissemination so that innovative solutions that could enhance collaborative actions could be taken, to bring criminal tricks to the fore. It could help in developing statistics about emerging crime in a fast changing world. Specifically the paper intends to provide empirical examination the impact of text based messages through mobile-phones mediated communication (MMC) on criminality and family crisis in South-South Geo-political region of Nigeria.

\section{Telecommunications revolution in Nigeria}

Telecommunications revolution is transforming the Nigeria society in divers' ways since the dawn of the new millennium. The introduction of ubiquitous mobile phones that serve for chatting and text messaging is providing a major tool in this revolution. The emergence of the Global System Mobile (GSM) put into effective check the monopoly of the Nigerian Telecommunication Limited (NITEL) on telephones. The introduction of mobile phones provided the needed tools to bridge existing digital divide. While government deregulation and liberalization policies provide a conducive ground for the emergence of global system mobile network providers, it discouraged the monopoly hitherto enjoyed by the Nigeria Telecommunication Limited and thus encouraged a substantial private sector investment in the telecommunications industry.

Prior to the advert of telecommunication revolution low private sector involvement and poor technology in the telecoms industry between1960-1999, had left the country with only 40,000 connected telephone lines and about 25,000 analogues. Tele-density was 0.4 lines per 100 inhabitants. This period is often described as the "dark age" of telecommunications in Nigeria (Ndukwe, 2003). However, between 2000 and 2008, there was great change in the sector as more than 2000 licenses were given to digital service providers, fixed wireless operators, internet service providers, and long distance operators (Ndukwe, 2005 ). Consequently, there was exponential increase in the numbers of telecommunication service providers. They include multinational companies like MTN, Vmobile now Zain, Globacom, Zoom, Starcom, Cisco, Intercellular, Mobitel, Multilinks, Mtel, Rainbownet, Reltel etc. This development led to annual growth rate of over one million lines and a market competition that reduces connection fees and increase access to telecommunication users. Teledensity also increased from 0.4 lines per 100 inhabitants in 1999 to 2.6 line per inhabitants in 2003. The number of connection on fixed lines equally increased from 450,000 to 1,120,000 line between 1999 and 2004 (Ndukwe, 2003, $2005^{\mathrm{b} \& \mathrm{c}}$ ). A recent research conducted by Pyramid shows that Nigeria had overtaken South Africa as the biggest mobile phone telecom market in terms of subscribers. With 61 million subscribers in 2008, the market had grown by 23 per cent with about 8.4 billion Naira in overall telecom service revenue; and a penetration rate of 42 equally percent (Toure, 2009).

Beside the reduction in connection fee and or cost of lines, the need to bridge the digital divides equally pushed down the cost of mobile phones which were initially prohibited. As part of a project initiated by the Global Trade Association (GTA) for the world's GSM mobile operators (GSMMO), Motorola Company was selected in 2005 to supply mobile phones that cost less than thirty United State Dollars (US \$30) to developing countries including Nigeria, India and South Africa (www.mongabay.com). The need to recognize Nigeria rural dwellers as information producers and users resulted in the installation of more satellite masks. With this development mobile phones have spread to the villages and are providing vital communication link to the rural people.

\section{Theoretical and empirical survey}

The advent of new technologies and the growing convergence of all media have major impact on information dissemination and communication. The new technologies on information and communication offer potentials for innovative social interaction, including peer and bottom-up communication (Marcelle, 2000). There exists equally creative opportunities for the creation, reproduction and dissemination of information relevant to economic development (Carrier, 1990). Three theories: the Technology Determinism Theory (Smith \& Marx, 1994; Green, 2001), Actor-Network Theory (Latour, 1992, 1997 \& Callon, 1999) and Social Presence Theory (Short, Williams \&Christie, 
1976), offer explanation for such creative opportunities. They equally seek to explain the relationship between technology and social change especially in the family, the basic unit of society.

According to Technology Determinism Theory (TDT) society's cultural values, social structure and history are all technology driven. The Theory posits that, rather than social context shaping technology, the uses made of technology determine the growth and development of the society. This implies that technology dictate users' behavior and action (Green, 2001). The implication of this postulates; is that cell phones (technology) exert large influence on the behavior of people including members of the family. The household factors such as marital status and relationship among couples could be improved or mar by mobile phone text-based messages; depending on the knowledge it exposes.

Actor-Network Theory (ANT) posits that, there is symbiotic relation between technology and its user. It holds that technology and human are equal interrelated actors in shaping society. Although, technology is created by humans its usage shapes human actions (Latour, 1992; Morphine \& Potts, 2003). The implementation of ANT to this study is that, cell phone (technology) and human beings are not equal actors in shaping what happens, in society including the family. It is no surprise therefore, that societies with most innovative scientists, universities engineers and technologies are not able to solve complex problems. Meaning that though mobile phones influence what goes on within the family in term of relationship, the magnitude of the effect depends on spouse attitude towards one another.

Just like the ANT, Social Presence Theory (SPT) examines the social effect of communication technology on society. The theory posits that, the social consequences of communication technology dependence on the level of visual and physical contact the medium allows it users to have. It holds that the more social presence or personal contact, the greater the intimacy, immediacy and harmonious interpersonal rap pour, it creates among users. It argues that, communication devices that are text-based, e-mail oriented create less social contact and thus have little influence on society /users. Judging within the perimeter of this postulate, cell phone do not cause great changes in the family; this is because, it usage do not allow for great personal contact. However, its influence on society (family) cannot be relegated to the background.

Mobile telecommunication is a technology which allows electronic transfer of two-way voice, graphic and text data. While it maintains its portability and roaming capability, it equally offers a range of services such as call blocking and forwarding, packet and network data services. The compatibility of the mobile telecommunications network and terminal equipment with the information superhighway facilitates, internet browsing, short message services (SMS), mobile shopping, mobile banking and other cyber-mediated activities (Samuel, 2008).

The role of telecommunication in knowledge creation has severally been acknowledged (Friedman, 2006); though the raw supply of knowledge is booming through ICT, the fraction that is use productively is plummeting to ever-lower depths (Quah, 2006). And since knowledge cannot be added up arithmetically, the only way we can tell if knowledge is in excess supply is by asking whether it is underused. Such consideration influences the concern on the vulnerability of the knowledge society in both micro-and macro-knowledge perspective. The mobile phone is enriched with the faculties of creating databases, music downloads and financial transaction, among others. By macro-knowledge, it means that the great forces that move history, the impact of new ideas, mass movement and technologies, changes in political system, the evaluation of geopolitical relations as well as the transformation of cultures, reach us daily (Samuelson, 2006). Ability to use these for the benefit of the society becomes a compelling issue.

As the global use of mobile phones increases, there are mixed feelings about its impact on society. According to Lynn (2008), mobile phones have made their way into all aspects of our culture in an invasive and dominating way. As the society is becoming increasingly technological base, mobile phone has become a steady companion for both the young and the old. A study in Great Britain on mobile phone usage shows that 36 percent of the students surveyed were addicted to their phones. About 7 percent of them lost their jobs and relationship over mobile phone use (Steve, 2008).

Mobile phone use while driving is responsible for most accidents across the globe. Consequently countries are making laws that prohibit its usage while driving (Hall, 2007). Mobile phone is also seen as security risk. Wrong information and signals are easily spread via mobile phone, and this can easily escalate panic. It is for these reasons that Federal Officials in the United State of America after September 11 attacks, worked out plans to close mobile phone networks to everyone but government officials in the event of another scenario as September, 11 (Blair, 2001).

Mobile phones allow kids to reach their parents and vice versa in the event of emergency. Again during family crisis, mobile phone is a companion to the left alone child, that could be used to accessed others members of the family and friends. It also enhances medical care (Cohen, 2009). Unfortunately, despite the advantages of mobile phones in the medical field, they are responsible for a fivefold increase in brain cancer among children and teenagers in Great Britain (Lean, 2008).

In Nigeria, mobile phones have been used severally in the duping crime business, popularly known as 419 . Victims have been asked to recharge phones to several amounts on the disguise of being neighbour or relatives, only to discover later that they have been duped. 


\section{Methodology}

The data reported here were obtained from a field survey on the impact of telecommunication industry on socio-economic development of the Niger Delta Region (NDR) of Nigeria. A detailed description of the study is yet to be published. The NDR of Nigeria has nine states including the six-Akwa Ibom, Bayelsa, Cross River, Edo, Delta and Rivers - in the South- South Geo-Political Zone (SSGPZ) of the country. The six states have 3 senatorial district each and one hundred and twenty three (123) local government areas in all. The National Population Census (NPC, 2006) put the population at $21,014,655$.

A cross -sectional survey which administered questionnaire on 7200 respondents elicited data for the study. Respondents whose age ranges from 18 to 58+ included men and women. Their marital status included those that were single, married, separated, divorced, widowed and widower. Other socio-economic characteristics of the respondents included type of occupation and educational attainment. Specific sections of the questionnaire elicited data on phone brand and phone line used by the respondents, the frequency of receiving and sending text based massages and experiences with text based massages and its implication.

The target population was residents of the six SSGPZ who subscribe to mobile telecommunications. We employed multistage random sampling techniques in the selection of respondents - with the help of the 1991 National Population Commission's (NPC) demarcated enumeration areas (EAs). From each state, we purposively selected one Local Government Area from each sensational district. We needed an urban based LGA where mobile phone subscribers are varied both in usage and network choice.

Beside, there is still a manifest digital derived between our rural and urban population. Urban dwellers still demonstrate the greatest affordability of access to mobile phones more than rural dwellers. Within each local government area, 10 enumeration areas were randomly selected, and within each enumeration area, 40 households were selected using a systematic random sampling technique for the administration of questionnaire. Consideration was given to gender equality in the administration of questionnaire such that if in the first household a man was interviewed, the next household would consider female respondents, except where such household was headed by a single parent, a bachelor or spinster. The study yielded a total sample size of 1,200 respondents a state and 7,200 respondents from the six states. Both descriptive and inferential statistics were employed in the analysis of data. We first presented the percentage distribution of responses for each variable and subsequently examined the bi-variants relationships between them. Prior to commencement of the study, the research protocol - including the study design, questionnaire, informed consent procedure and means of preserving respondents, confidentiality - was reviewed and approved by the research committee of AKMUM DEVELOPMENT CONSULTS LIMITED, Calabar, Nigeria.

\section{Research findings}

\subsection{Socio-Demographic Back Ground of Respondents}

As shown in Table 1, there was significant difference in the age range of the respondents $\left[x^{2}, 8(n=7,200)=2060.32\right.$, $\mathrm{p}=0.00]$. More than a half of the respondents $(\mathrm{N}=3,736,51.88 \%)$ were within the age bracket of $18-32$ years. The overall means age was $34.96(\mathrm{SD}=5.91)$ years. The gender distribution was 3,694 (51.31\%) men and 3,506 (48.69\%) female. $\left[\mathrm{X}_{3}^{2},(\mathrm{~N}=7200)=9.82, \mathrm{p}=0.00\right)$. Majority of them were married $(\mathrm{N}=3,818,53.03 \%)$. The rest were either single ( $\mathrm{N}=1,986,27.58 \%)$, separated $(\mathrm{N}=437,6.07 \%)$, divorced $(\mathrm{N}=898,12.47 \%)$ or widowed/widower $(\mathrm{N}=61,0.85 \%)$ $\left[\mathrm{X}^{2}, 4(\mathrm{~N}=7200)=7946, \mathrm{p}=0.00\right]$. One thousand nine hundred and eighty six thousand $(27.58 \%)$ of the respondents earned their income from the civil service employment, while 2,192 (30.44\%) were engaged in the private sector. There were more applicants $(\mathrm{N}=1740,24.17 \%)$ than students $(1,075 ; 14.93 \%)$ among the respondents. While $89(1.24 \%)$ of the respondents were corpers serving the mandatory one year National Service, $647(8.99 \%)$ of them were self-employed, [ $\left.\mathrm{X}^{2}, 5(\mathrm{~N}=7500)=2894.47, \mathrm{p}=0.00\right]$.

Table 1 equally reveals the educational attainment of the respondents. The literacy level was high. Less than 4 percent of the respondents had the West African School Certificate. About 29 per cent $(\mathrm{N}=2,094)$ had Diplomas/OND/NCE, while 43.26 per cent $(\mathrm{N}=3115)$ of them held University first degrees and Higher National Diploma. About 24.06 percent $(\mathrm{N}=1,732)$ of them had higher degrees, $\left[\mathrm{X}^{2}, 3(\mathrm{~N}=7,200)=3107.38, \mathrm{p}=0.00\right]$

\subsubsection{Mobile phone ownership and phone lines}

A significant difference in the type of phone used by the respondents was demonstrated during the study, $\left[\mathrm{X}^{2}, 7\right.$ $(\mathrm{N}=7200)=3,945.71, \mathrm{P}=0.00]$. A large number of the respondents $(\mathrm{N}=2,256)$ representing 31.33 per cent of the populations of study owned mobile phones that were Nokia Brand. This was followed by Samsung ( $\mathrm{N}=1253,17.40 \%)$, Sagem $(\mathrm{N}=1095,15.21 \%)$, Sunny Erikson $(\mathrm{N}=907,12.60 \%)$ and Motorola $(\mathrm{N}=764,10.61 \%)$. Acatel, Sendo and Simens brand were used by 449 (6.34\%), $99(4.15 \%)$ and $177(2.46 \%)$ of the respondents respectively. This significant disparity is better demonstrated in Figure I. It suggests the popularity of the Nokia brand of mobile phones in the study area. Although several factors, ranging from price, design, distribution, etc (variable that were not considered in this study) 
may contribute to the brands popularity. The study reveals that nearly all mobile phones brand available in the market were found in the study area.

When respondents choice of phone line was requested, more than 29 per cent of them $(\mathrm{N}=2107)$ were using MTN line. This was followed by Global Com network $(\mathrm{N}=1778,24.69)$ and Zain $(\mathrm{N}=1368,19 \%) .1204(16.72 \%)$ of the respondents were using Etisalat, while Reltal, Starcom and Visafone were 339 (4.71\%), 239 (3.32\%) and 165 (2.29\%) of the respondents, respectively $\left[\mathrm{X}^{2}, 6(\mathrm{~N}=7200)=4214.14, \mathrm{p}=0,00\right]$. The disparity in line usage among respondents is demonstrated in Figure2. This finding suggests high patronage of MTN in the study area. Again this may be due to a number of factors, which were beyond the scope of this study.

\subsubsection{Frequency of receiving and sending text based massages}

Table 2 provides a comparative data of respondents' frequency of receiving and sending text based messages through mobile-phone mediated communication (MMC). A chi-square analysis of the difference, was significant $\left[\mathrm{X}^{2}, 4\right.$ $(\mathrm{N}=7200)=81.27, \mathrm{P}=0.00$ ]. Except on special occasions (occasionally) respondents frequency of receiving text based massages was higher than that of sending text based messages. For instance, on a daily basis, $2169(30.13 \%)$ respondents acknowledged receiving text messages through their phone, while 2011 (29.93\%) acknowledge sending text messages. In a similar manner, 5,729 (79.49\%) received text based massages weekly while 4,819 (66.93\%) send out text message per week. This finding was not different when the monthly frequency was examined. More receivers $(\mathrm{N}=6,249,86.79 \%)$ than senders $(\mathrm{N}=5,315,73.82 \%)$ of text based messages were recorded. This finding suggests the popularity of text based messages through mobile phones. Although nearly every text message received elicits a response, the findings suggest that many unsolicited text messages received are not responded to. However, occasion like birthday, festivities, etc, increases the frequency of receiving text messages than sending.

Surprisingly, there was no respondent who had never send nor received text message through his or her mobile phone. This suggests the multipurpose use of the mobile phone and the dependability of phone for receiving and sending text based messages.

\subsubsection{Experiences with text based message through mobile phone mediated communication (MMC)}

Respondents' experiences with mobile phone text messages were categories into three stages. At the first stage, we assessed respondents' experiences as criminal victims, through mobile encounter. At the second stage we assessed family/personal problem caused as a result of receiving and or sending mobile phone text based messages. Finally, we assessed the outcome of both stage 1 and 2 in terms of the lost suffered.

As shown in Table 3 respondents experiences significantly differed whether as criminal victims, or personal /family problem incurred through receiving and sending of text base messages $\left[\mathrm{X}^{2}, 5(\mathrm{~N}=7200)=1405.32, \mathrm{P}=0.00\right]$. More than a half of the respondents $(\mathrm{N}=4,511,62.65 \%$ experienced "attempts to defraud" through the mobile phone text message, while $\left[\mathrm{X}^{2}, 4(\mathrm{~N}=7200,=8461.70, \mathrm{P}=0.00] 1,005(13.95 \%)\right.$ were out rightly defrauded. The number of respondents that received text based messages that turned out to be lies $(\mathrm{N}=3,612,50.17 \%)$ were higher than those who received false alarm $(\mathrm{N}=2,135,29.65 \%)$. A negligible number $(\mathrm{N}=98,1.36 \%)$ received threats to their life through mobile phones.

When family/personal problems were assessed, 1,579 (21.93\%) of the respondents said they discovered they were being cheated by their husbands through text based messages, while $1,243(\mathrm{~N}=17.26 \%)$ of the respondents said they were being cheated by their wives through text based messages. Other respondents $(\mathrm{N} 715 ; 9.93 \%)$ and $(\mathrm{N} 271,3.76 \%)$ believed they were being cheated by their fiancé and fiancé respectively through text based messages. The Table further reveals respondents experience of being cheated by their boy friends' $(\mathrm{N}=923,12.82 \%)$ and "girl friends" $(\mathrm{N}=605$, $8.4 \%$ ) through text based message.

The outcome of falling victims to criminals through text based messages either through lies, frauds, threat to life and or false alarm; and being cheated by spouse, and or friends result in social problems that threaten peaceful co-existence. While $67(0.93)$ of the respondents lost their life-saving as a result of mobile phone fraud, $125(1.74 \%)$ of them have continued to live in fear. For majority of the respondent, $(\mathrm{N}=4,036,56.06 \%)$, the discovery of being cheated through text based messages by their spouses and or friends had generated quarrel among them. Other had to resort to suspicion $(\mathrm{N}=1,336 ; 18.56 \%)$, fighting $(\mathrm{N}=918,12.75 \%)$ and warning $(\mathrm{N} 526 ; 7.31 \%)$. More than a third of the respondents $(\mathrm{N}=3,153, \mathrm{~N}=43.79 \%)$ had lost confidence in their relationship; while $78(1.08 \%)$ of the respondents settled for divorce, $1007(1.45 \%)$ of them called for separation.

\section{Discussion}

At the advent of information technology, media experts had predicted that it would usher in knowledge based society full of leisure (Smith, 2006). Emerging misinformation and distortion of information due to access by criminals has challenged that prediction. ICT is not only entertaining and informative but also a source of money for many users. And many users of ICT have been counting their lost. As revealed by this study text based message through mobile-phone 
mediated communication (MMC) is popular among all mobile phone subscribers. There is hardly any mobile phone subscriber that has never received and or sent text based messages.

Despite the higher literacy level of the respondents in this study, many of them have been duped through text based messages sent through their phones. Others have received threat to life as well as false alarm. The implications of such text based messages are obvious. Many respondents who could not wait to verify the source of such information were defrauded of their savings. By conveying "threat to life" messages, mobile phone has become a source of fear, more so when the senders of such messages could not be traced.

Recently text based messages that warned subscribers about eating apple were received. The sender of the message even went on to emphasize that the National Agency for Food, Drug Administrator and Control (NAFDAC) was aware of the killer apple. In responses, the consuming public avoided apple. It was when apple sellers cried out that NAFDAC was aware of the text message, and inform the public that it was a false alarm. The implication of such alarm could result in ignoring genuine information in the future on the suspicion that it may be like the apple story.

Among young couples text based messages appear to have replaced letter writing. Love messages through text have received a prime of place. And because such messages could be stored and retrieved at will, other people who have access to the mobile phone could access such information. Others have stored pornographic photographs and six movies which they could watch at their convenience. Others have stored photographs of love ones, and dating alarm. In this study, there were counter accusations of cheating between husbands and wives, fiancé and fiancée as well as boyfriends and girl friends such accusations originate from access to and or outright suspicious that the other partner has been dating someone else or making love advances through text messages in mobile phones for many couples such discovery resulted in divorce $(\mathrm{N}=78,1.08 \%)$, while other marriages ended in separation $(\mathrm{N}=107,1.49 \%)$. Such could be traumatic and call into question basic human relationships.

Where families are constantly quarrelling $(\mathrm{N}=4,036,56.06 \%)$ and suspicious $(\mathrm{N}=1,336 ; 18.56 \%)$, there is a tendency for continuous misunderstanding that could result in fighting $(\mathrm{N}=918,12.75 \%)$. When families deteriorate to such level, child rearing and upbringing suffer. This has a serious implication for the society.

\section{Conclusion}

Telecommunications revolution especially the use of mobile phones is accelerating significant change in Nigeria society. There is a fundamental shift in the pattern of communication and human relationship with the introduction of text based messages through Mobile-phone Mediated Communication (MMC). This medium made it possible for people to receive and send messages without physical contact, and these messages can be retrieved at will. This revolution also fosters socio-economic development through the creation of new types of economic activities, employment opportunities, telecom- medical- care and human empowerment. Despite these advantages and more, findings from this study revealed that MMC has been employed into criminal activities such as frauds, threat to life, false alarm, lies etc. Text-based messages that suggest spouse cheating on the other has also been a source of family crisis and ill relationships among fiancé and fiancée, boyfriends and girlfriends etc. We therefore recommended that, legislature should be put in place to regulate and ensure that every sim card user in Nigeria is properly registered. And that spouses and the general public should scrutinize text messages before reacting to its contents.

\section{References}

Blair, J. (2001). A nation challenged: Telecommunications U.S considers restricting cell phone use in disasters. The New York Times. [Online] Available: Http//query.nytimes.com/gst/fullpage.html (August 25, 2009).

Callon, M. (1999).Some elements of a sociology of translation: Domestication of the scallops and the fishermen of saint brieuc bay. In M. Biagioli (Ed.), The Science Study Reader (pp.67-83). New York: Routledge.

Carrier, J. (1990). Reconciling commodities and personal relations in industrial society. In R. Silverstone E. Hirsch \& D. Morley (Eds.), Consuming technologies (pp. 1-29). London: Rodledge.

Cohen, M. (2009). Cell phones at school: should they be allowed? [Online] Available: http://life.familyeducation.com.cellular-telephones/school/51264.html (August 25, 2009).

Friedman, T. L. (2006, December -February). The exhausting race for ideas. Newsweek (Special Edition.) Pp. 11-12.

Giddens, A. (2006). Sociology (5 ${ }^{\text {th }}$ ed.) Malden: Polity Press.

Green, L. (2001). Techno-culture. Crows Nest: Allen and Unwin.

Hall, G. (2007). How to avoid the downsides of using cell phones. In L. Steve (Ed.), [Online] Available: http://usacellsearch.com/tag/cell-phone-use (August 25, 2009).

Keil, M., \& Johnson, R.D. (2005).Feedback channels: Using social presence theory to compare voice mail to e-mail. Journal of Information Systems Education, 13 (4), 295-302. 
Latour, B. (1992). Where are the missing masses? The sociology of a few mundane artifacts. In W.Bijiker \& J.Law (Eds.), Shaping Technology/Building Sociology. Cambridge: MIT Press.

Latour, B. (1997). On actor network theory: A few clarifications. [Online] Available: http://en Wikipedia.org/wiki/actor network Theory (November 22, 2007).

Lean, G. (2008). Mobile phone use raises children's risk of brain cancer fivefold. Independent News. [Online] Available:http//www.independent.co.uk./news/science/

mobile-phone-use-raises-children-risk-of-brain-cancer-fivefold-937007.html(August 25, 2009).

Lynn, K. (2008). In L. Steve (Ed.), Cell phone etiquette. http://usacellsearch.com/tag/cell-phone-sue (August 25, 2009).

Marcelle, G (2000). The economics of ICT: Challenges and practical strategies of ICT used for women's economic empowerment. Kuala Lumpur: VAM.

Murphie, A. \& Potts, J. (2003). 'I", culture and technology. London: Palgrave

Nath, V. (2000). Empowerment and governance through information and communication technologies: Women's perspective. paper presented at the international conference on women in the new ict era: challenges and opportunities. kuala lumpur, malaysia, 22-24 october, 2000. [Online] Available:http:www.cddc.vt.edu/knownet/articles/women and ICT.htm(August 25, 2009).

National Population Commission. (2006). National census report. Abuja: Government Printing Press.

Ndukwe, E. (2003). The role of telecommunications in national development. $19^{\text {th }}$ omolayole annual management lecture at Chartered Institute of Banks' Auditorium, Victoria Island, Lagos, Nigeria.

Ndukwe, E. $\left(2005^{\mathrm{a}}\right)$. Three years of gsm revolution in nigeria. [Online] Available: http//www.ncc.gov.ng/speeches_presentations/Evc's(August 20, 2005).

Ndukwe, E. $\left(2005^{\mathrm{b}}\right)$.Telecoms regulatory environment. [Online] Available: http//www.ncc.gov.ng/speeches_presentations/Evc's(August 20, 2005).

Ndukwe, E. $\left(2005^{\circ}\right)$. Developing telecommunications infrastructure. [Online] Available: http//www.ncc.gov.ng/ speeches_presentations EVc's(August 20, 2005).

Offurum, S.C. (2009, May 31). Communication revolution. The Leader, 1, 19, p. 2.

Otite, O. \& Ogionwo, W. (2006). An introduction to sociological studies. Ibadan: Heinemann Educational Books.

Quah, D. (2006, December -February). Knowledge glut. Newsweek (Special edition). Pp. 43.

Samuel, K. J. (2008). Can mobile telecommunication reduce intra-city work travel? Empirical evidence from a third world city. Ibadan Journal of the Social Sciences, 6(1), 45-54.

Samuelson, R. .J. (2006- December, -February). The stealth factor. Newsweek (Special edition). Pp. 74-75.

Short, J.A., Williams, E. \& Christie, B. (1976). The social psychology of telecommunications. New York John Wiley and Sons.

Silverstone, R., Hirsch, E., \& Morley, D. (1992). Consuming technologies. London: Rodledge.

Smith, M. R. \& Marx, L. (1994). Does technology drive? The dilemma of technological determinism. Cambridge: MIT Press.

Steve, L. (2008). The growing problem of cell phone addiction. [Online] Available: http://usacellsearch.com/tag/cell-phoneuse(August 20, 2009).

Toure, H, (2009, March). Mobile phone banking: View point. Africa Global Perspective. Pp. 56-57.

Trevino, L.K, Webster, J., \& Stein, E.W. (2006). Making connections; Complementary influence on communication media choice, attitude and use. Organization Science, 2 (2), 163-182. 
Table 1.

\begin{tabular}{|c|c|c|c|c|c|c|}
\hline Variables & $\mathbf{N}$ & $\%$ & $\mathbf{M}$ & SD & $\mathbf{X}^{2}$ & $\mathbf{P}$ \\
\hline Age & & & 34.96 & 5.91 & $2060.32_{8}$ & 0.0000 \\
\hline $18-22$ & 1019 & 14.15 & & & & \\
\hline $23-27$ & 1433 & 19.90 & & & & \\
\hline $28-32$ & 1284 & 17.83 & & & & \\
\hline $33-37$ & 638 & 8.86 & & & & \\
\hline $38-42$ & 489 & 6.79 & & & & \\
\hline $43-47$ & 1039 & 14.43 & & & & \\
\hline $48-52$ & 784 & 10.89 & & & & \\
\hline $53-57$ & 335 & 4.65 & & & & \\
\hline$\geq-58$ & 179 & 2.49 & & & & \\
\hline \multicolumn{7}{|l|}{ Gender } \\
\hline Male & 3,694 & 51.31 & & & 9.82 & 0.0017 \\
\hline Female & 3.506 & 48.69 & & & & \\
\hline Marital status & & & & & $7946_{4}$ & 0.000 \\
\hline Single & 1986 & 27.58 & & & & \\
\hline Married & 3818 & 53.03 & & & & \\
\hline Separated & 437 & 6.07 & & & & \\
\hline Divorced & 898 & 12.47 & & & & \\
\hline Widow/widower & 61 & 0.85 & & & & \\
\hline Occupation & & & & & $2897.47_{5}$ & 0.0000 \\
\hline Civil servant & 1457 & 20.24 & & & & \\
\hline Private sector & 2192 & 30.44 & & & & \\
\hline Self-employed & 647 & 8.99 & & & & \\
\hline Students & 1075 & 14.93 & & & & \\
\hline Corper & 89 & 1.24 & & & & \\
\hline Applicants & 1740 & 24.17 & & & & \\
\hline Education & & & & & $3107.38_{3}$ & 0.0000 \\
\hline$\leq \mathrm{WASC}$ & 259 & 3.60 & & & & \\
\hline Diploma/OND/NCE & 2094 & 29.08 & & & & \\
\hline Degree/HND & 3115 & 43.26 & & & & \\
\hline Higher Degree & 1732 & 24.06 & & & & \\
\hline
\end{tabular}


Table 2.

\begin{tabular}{|c|c|c|c|c|}
\hline Frequency & Receiving (\%) & Sending (\%) & $\mathbf{X}^{2}$ & $\mathbf{P}$ \\
\hline \multirow[t]{2}{*}{ Daily } & $2169(30.13)$ & 2011 & $81.27_{4}$ & 0.000 \\
\hline & & $.93)$ & & \\
\hline \multirow[t]{2}{*}{ Weekly } & $5723(79.49)$ & 4819 & & \\
\hline & & $5.93)$ & & \\
\hline \multirow[t]{2}{*}{ Monthly } & $6249(86.79)$ & 5315 & & \\
\hline & & $3.82)$ & & \\
\hline \multirow[t]{2}{*}{ Occasionally } & $6810(94.58)$ & 6950 & & \\
\hline & & $5.53)$ & & \\
\hline \multirow[t]{2}{*}{ Once in a while } & 479 (4.79) & 516 & & \\
\hline & & 17) & & \\
\hline Never & - & - & - & - \\
\hline
\end{tabular}

Frequency of receiving and sending text based messages through MMC

Source: Field work (2009)

Table 3 .

\begin{tabular}{|c|c|c|c|c|c|}
\hline & Experiences & $\mathbf{N}$ & $\%$ & $\mathrm{X}^{2}$ & $\mathbf{P}$ \\
\hline \multirow[t]{6}{*}{$\mathbf{A}$} & As victims of: & & & $8461.70_{4}$ & 0.0000 \\
\hline & Lies & 3,612 & 50.17 & & \\
\hline & Frauds & 1,005 & 13.95 & & \\
\hline & Attempts to defraud & 4,511 & 62.65 & & \\
\hline & Threats to life & 98 & 1.36 & & \\
\hline & False alarm & 2,135 & 29.65 & & \\
\hline \multirow[t]{7}{*}{ B } & Being cheated by your: & & & $1405.32_{5}$ & 0.0000 \\
\hline & Husband & 1,579 & 21.93 & & \\
\hline & Wife & 1,243 & 17.26 & & \\
\hline & Fiancé & 715 & 9.93 & & \\
\hline & Fiancée & 271 & 3.76 & & \\
\hline & Boy friend & 923 & 12.82 & & \\
\hline & Girl friend & 605 & 8.40 & & \\
\hline \multirow[t]{10}{*}{ C } & Outcome of A \& B & & & & \\
\hline & Loss a life saving & 67 & 0.93 & & \\
\hline & Live in fear & 125 & 1.74 & & \\
\hline & Quarrel & 4,036 & 56.06 & & \\
\hline & Suspicion & 1,336 & 18.56 & & \\
\hline & Fighting & 918 & 12.75 & & \\
\hline & Warning & 526 & 7.31 & & \\
\hline & Loss confidence & 3,153 & 43.79 & & \\
\hline & Call for divorce & 78 & 1.08 & & \\
\hline & Call of separation & 107 & 1.49 & & \\
\hline
\end{tabular}

Respondents experiences with text based message through $\mathrm{MMC} ; \mathrm{N}=7200$

Source: Field work (2009) 


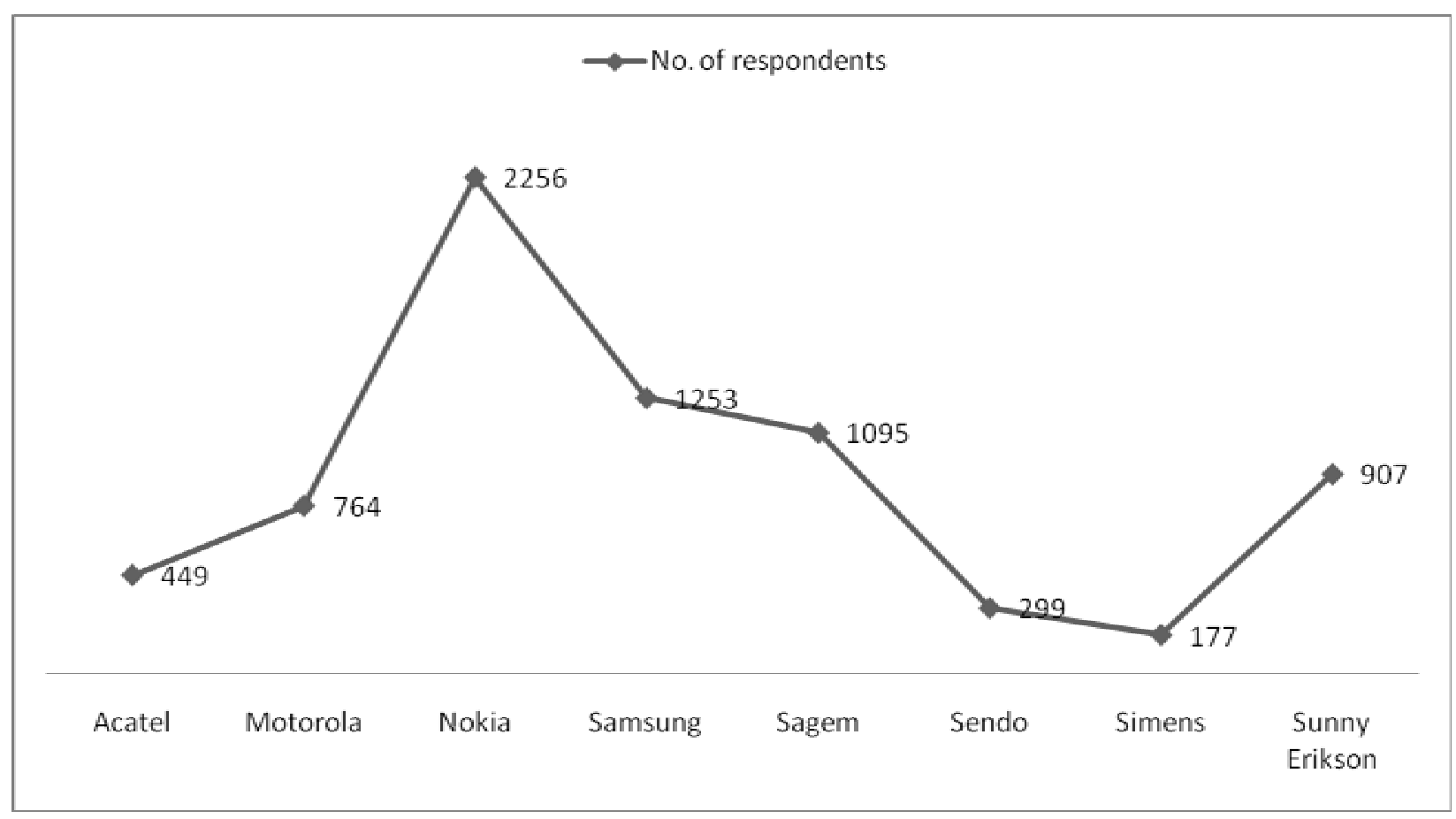

Source: Field work (2009)

Figure 1. Distribution of phone brand by respondents

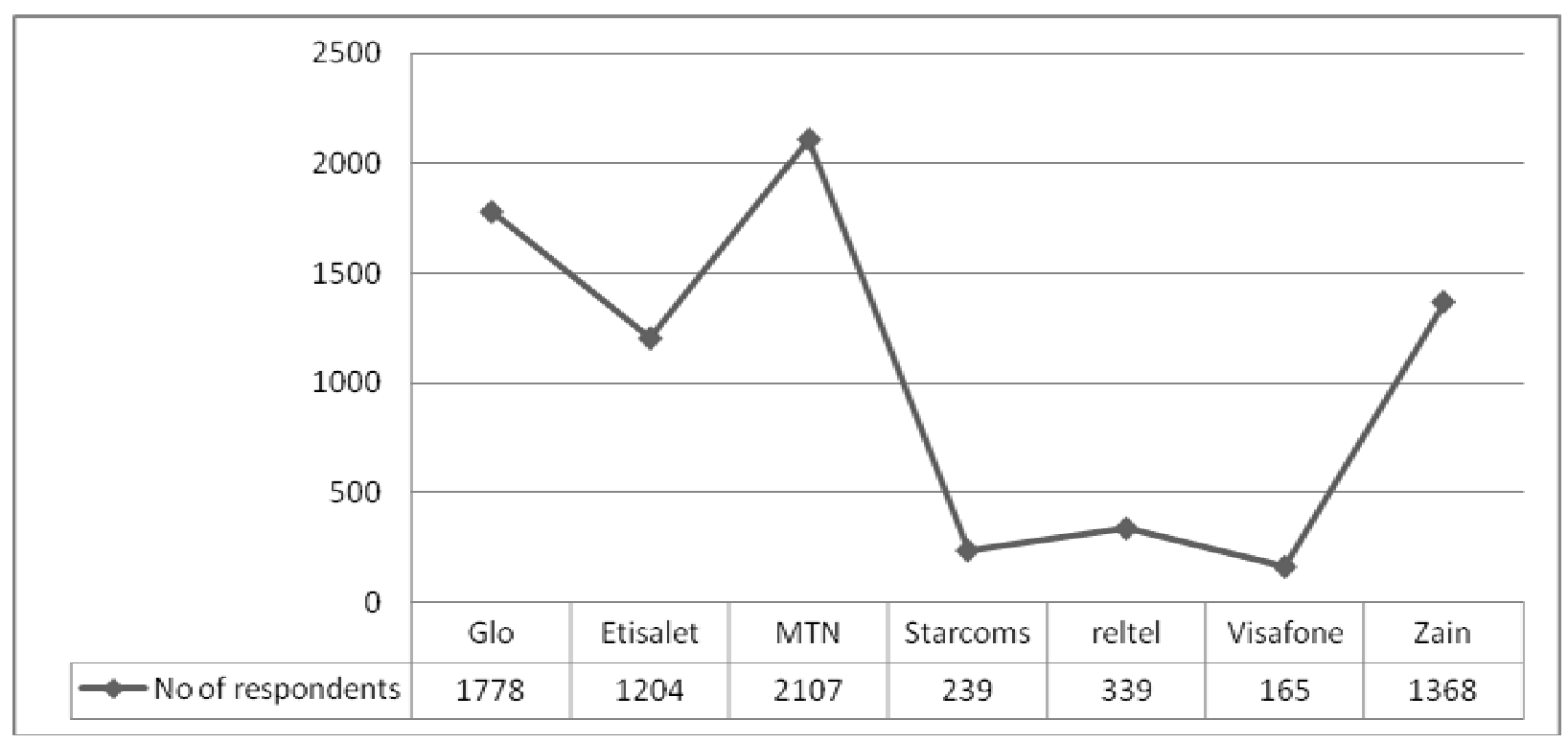

Source: field work (2009)

Figure 2. Distribution of phone lines by respondents 